\title{
ON SPECIFIC ZOOLOGICAL ISOGLOSSES \\ BETWEEN CELTiC AND (BALTO-)SLAVIC
}

\author{
VÁCLAV BLAŽEK
}

\section{Introduction}

In this contribution, I shall be dealing with three major questions:

(1) Was 'eagle' in Celtic and Balto-Slavic extended in $-l$ - or in $-r-$ ?

(2) Can Balto-Slavic 'swan' be etymologised as 'beaked' with the help of Celtic?

(3) Can words for 'fox' be based on a Celto-Baltic or Celto-Slavic isogloss?

\section{Celtic and Balto-Slavic words for 'eagle'}

Words to denote 'eagle' in Balto-Slavic and Celtic languages are similar, but it is difficult to find a common lexeme from which both were derived:

Baltic *arelijas 'eagle' > Lithuanian erẽlis, gen. -io, Old (Szyrwid) \& dial. (East) arẽlis, dim. (Szyrwid) arelaitis 'pullus aquilae', pl. arelinis; Latvian èrglis (Gospel 1753) and in Bērzgale and Kārsava erelis, Upper Latvian nom. pl. ereļi (Fraenkel 1962-4: 122; Smoczyński 2007: 146-7; Mühlenbach \& Endzelin 1925: I.570, 575; Endzelin \& Hausenberg 1934: I.370; the spelling of the beginning of the word with $e$-rather than with $a$ in Standard Lithuanian and Latvian is explained by Lex Rozwadowski, cit. from Andersen 1996: 141), Prussian arelie, in Elbing Vocabulary \#709 gl. are, i.e. in modern German aar 'eagle', corr. *arelis (Mažiulis 1988: I.90; Toporov 1975-90: I.101), Narewian adtif < *ardlis id. (according to Zinkevičius 1984: 8, a borrowing from German Adler is less probable).

Slavic *orblb 'eagle': Old Church Slavonic orblb, Bulgarian, Macedonian orél, Serbo-Croatian òrao, gen. órla, Slovenian órol, Slovak orol, Czech orel, Upper Sorbian worjot, Lower Sorbian jeret, Polabian viŕål, Polish orzet, Old Russian orblı, Russian orël, gen. orlá, Ukrainian orél, gen. orlá/virlá id. (Vasmer 1953-8: III.150-1; Schuster-Šewc 1984: 1661).

Goidelic: Old Irish irar, $^{1}$ Middle Irish ilar $^{2}$ m. 'eagle' [o-stem], ilur gl. aquila, dim. ilarán (DIL I 62.17ff).

\footnotetext{
${ }^{1}$ See Thurneysen (1918: 61): "Die altirische Form des Wortes, das mittlelir. ilar, neuir. iolar, kymer. eryr, mbret. erer (korn. neubret. er) lautet, ist bisher an der einzigen mir
} 
Brittonic: Middle Welsh erer, Welsh eryr 'eagle; hero, chief, prince, leader', m. \& f., pl. eryrod, eryron, Old Cornish er, Middle Breton erer m., Modern Breton er m. 'eagle' (Pedersen 1909: I.491, §336; GPC: I.1240; Matasović 2009: 117-8).

There have been several attempts to explain the relation between the insular Celtic and Balto-Slavic designations of 'eagle'.

Schulze (1908: 342-7) collected several animal names extended in $l$ - which were meant to support his idea that Slavic *orblb 'eagle' and Baltic *arelis are derived by the same suffix:

Old Indic gavala- 'wild buffalo': gav- 'cattle, bull', chagalá'buck': chágga- 'he-goat', chág $\bar{a}$ 'she-goat'.

Latin capreolus: caprea, cf. French chevreuil 'Rehbock', Old Provençal chevrol, Italian capriulo, Romanian căpriór.

Old Icelandic gymbill 'he-lamb': gymbr 'ewe lamb', similarly ekkill 'widower': ekkja 'widow'.

Slavic *kozblb 'he-goat': *koza 'she-goat'.

Schulze (1908: 343ff.) saw the same suffix in the $l$-extensions of words meaning 'big, plenty', e.g. Old Indic bahú-: bahulam; Greek

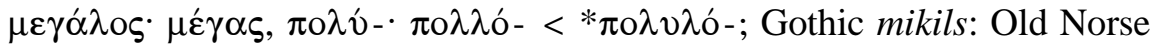
mjok <*megu-; Lithuanian didis 'big': didelis, daũg: daũgel 'many'.

However, Thurneysen (1918: 61) did not agree with him:

Ir. irar, kymr. eryr gehen auf *eriros zurück (fn. 2: vgl. Pedersen I: 491). Das zeigt, daß slav. orblb aus *orbrb dissimiliert ist (noch weiter verändert lit. erẽlis) und nicht mit W. Schulze, JagićFestschr. 343ff., benutzt werden kann, um eine urindogermanische Augmentativbildung mit $l$-Suffix zu erweisen. Auch seine übrigen Beispiele kommen mir nicht recht beweisend vor. Got. mikils, ahd. mihhil erklärt man mit Wahrscheinlichkeit als Anbildung an gegensätzliche Ausdrucke wie got. leitils ahd. luzzil und so wird es sich auch mit gr. $\mu \varepsilon \gamma \alpha \lambda \mathrm{o}-$ und ähnlichen verhalten. Wie der Ablaut in den Vogelnamen hineingekommen ist, ist schwer zu sagen (fn. 3: Pedersen stellt auch arm. oror urur 'Möve, Weihe' dazu).

bekannten Belegenstelle nicht erkannt worden. Es ist der Vers, den K. Meyer, Fiannaigecht 30.16, aus Laud 610 druckt: Dāre Doimthech (ba) ri for Mbruig is é ém irar ìrar ngail, 'Dare Doimthech (war) König über Mruig, er ist wahrlich ein Adler an Tapferkeit"".

${ }^{2}$ delbh ilair do dergór alainn, aithlegtha fura barr 'and the figure of an eagle, of beautiful, red, refined gold, on the top of the shaft' (see Robinson 1908: 59, 138). 
Vielleicht wurzelte die Form or- ursprünglich in der $n$-Bildung: an. grn ahd. arn gr. öpvīs. Ob got. ara ahd. aro usw. zu dieser gehört oder durch Haplologie entstanden war wie korn. nbret. er, ist zweifelhaft.

Later Thurneysen (1946: 104, §166) added: “Old Irish irar 'eagle', which together with Welsh eryr points to a primary form *eriros, the neutral $-\rho-$, despite the $-i-$, is yet unexplained".

Let us mention that Pedersen's and Thurneysen's reconstruction *eriro- is not the only possibility of the insular Celtic starting-point. For example, Stokes (1894: 39) reconstructed *eruro- and Toporov (1975-90: I.101) even *erilo-.

It is also impossible to answer unambiguously whether it was the $l$ or $r$ - extension in the Celtic and Balto-Slavic designations of 'eagle'. Schulze had collected several zoonyms from various IE branches which were apparently extended by the $l$-suffixes. His examples are valid, independently of any relation to the words for 'big' and 'little' discussed in the polemics of Thurneysen. It is possible to add Latin aquila 'eagle' and Germanic *fuglaz 'bird', independently of its further etymology, whether from Germanic *fleugan ${ }^{a n}$ 'to fly', and further to Lithuanian plaũkti 'swim', or to Lithuanian paũkštis 'bird' (Buck 1949: 183, §3.64). But there is also the $r$-suffix forming some of the bird-names, e.g. Latin passer 'sparrow', hanser 'gander' vs. Slavic *goserb id.: *gosb 'goose'. Taking in account the external parallels, it is possible to quote two proper names:

(a) Gaulish toponym Orilus 'Rupertsberg by Bingen' (Holder II.877).

(b) Palaeo-Balkanian name of the Thracian leader "'O $\lambda$ opos

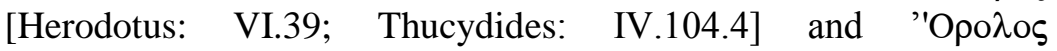
[Marcellinus, Vita Thuc. 2], and the Dacian king Oroles [Pompeius Trogus, Hist. XXXI, 3.16] (collected in Detschew 1957: 341; Kretschmer 1896: 214).

Both names agree in the initial $o$ - and the derivational suffix $-l$ Unfortunately, their meaning remains unknown, and so they cannot play any substantial role in our solution, although 'eagle' belongs to the most beloved motives in both anthroponymics and oronymics. 
But this is not the main problem regarding the compatibility of the Celtic and Balto-Slavic data. The most difficult is the difference in initials: Celtic $*_{e}$ - vs. Balto-Slavic $*_{o}$ - indicate the only possible ablaut pair ${ }^{*} H_{l} e$ - vs. ${ }^{*} H_{1} O-$, while the Anatolian counterparts, Hittite haras, gen. haranas, Palaic ha-ra-a-as(-) 'eagle', Cuneiform Luwian harran(i)- 'a bird' ${ }^{3}$ are derivable only from ${ }^{*} \mathrm{H}_{3} \mathrm{er}^{\mathrm{o}}$ or ${ }^{*} \mathrm{H}_{2} \mathrm{er}^{\mathrm{O}}$. The Germanic (*aran- > Gothic ara, Old Norse ari and orn < *arnu-, Old High German aro \&

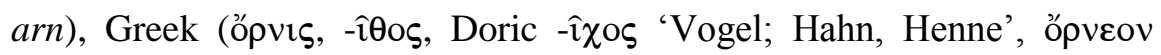
'bird') and Armenian (ori 'raven', Olsen 1999: 442) cognates are derivable from ${ }^{*} H_{3} e r^{\circ}$ or from the $o$-grade ${ }^{*} H_{1 / 2 / 3} O r^{\circ}$. Summing up, with regard to the existing reconstructions, the Celtic designation of 'eagle' is not compatible with its Anatolian semantic counterpart. There are three possibilities:

(a) Celtic 'eagle' is related to the Balto-Slavic, Germanic and Greek forms - the initial laryngeal was ${ }^{*} H_{l^{-}}$, excluding the Anatolian data.

(b) Anatolian 'eagle' is related to Greek, Germanic and BaltoSlavic - the initial laryngeal was $* H_{3^{-}}$or ${ }^{*} H_{2^{-}}$, excluding the Celtic data.

(c) All forms are related only in the case of a wrong reconstruction of the insular Celtic protoform in $* e$-.

Let us try to verify the possibility (c). This entails revising all steps in the reconstruction of the Celtic protoform.

In agreement with the traditional reconstruction *eriro-, the Middle Irish form ilar implies a dissimilation of the type $r . . . r>l \ldots r$. Although it is not directly attested, it is perhaps possible; an analogical dissimilative process $l . . . l>r . . . l$ or $r . . . l$ explains such forms as Old Irish aile 'other', alaile and araile 'the other', Welsh arall and ereill 'another', Breton and Middle Welsh eil 'second', or Irish lemlacht 'sweet milk' vs. Old Cornish leverid id. (Thurneysen 1946: 119, §192b; 307-9, §§486-8). But with regard to the exceptional attestation of the form irar, ${ }^{4}$ the form ilar may represent an original starting point. If the Old/Middle Irish final ${ }^{\circ}[C] a r$ is derivable from $*^{\circ}[C]$ ros or $*^{\circ}[C] \breve{V}$ ros (see de Bernardo Stempel 1999:

\footnotetext{
${ }^{3}$ Cf. also the Lycian dynastic name Xerẽi (HED: III.137-9; Kloekhorst 2008: 301).

${ }^{4}$ See Thurneysen (1918: 61) at fn. 1 above; an artificial hypercorrection cannot also be excluded.
} 
317), it is also possible to think about a hypothetical pre-Goidelic protoform *iloros or *eloros and via metathesis from **orilos or **orelos. The following examples can illustrate that metathesis of this type operated in Celtic:

(i) Middle Irish criol vs. clior (Pedersen 1909: I.493).

(ii) Old Irish ónn uraid gl. ab anno priore, Middle Irish innuraid 'from last year' < *per-uti via metathesized (?) *irud (Griepentrog 1995: 445 , fn. 5) with the word for 'year' in the zero-grade and loc. sg., or < *per-utem in the fossilized accusative, as it is possible to understand from the form of the definite article (Schrijver 1995: 244, 257; Matasović 2009: 128).

(iii) Celtic verbal base *kli-nu- <*klu-ni- 'to hear' (Thurneysen 1946: 357; Kümmel in LIV: 335, fn. 8; Schumacher 2004: 413). The phenomenon of metathesis opens new paths in connection of presumably otherwise incompatible Celtic and Balto-Slavic forms.

In Brittonic, $i$-umlaut of the type $*_{o} \ldots \breve{\bar{l}}>e_{\ldots i}$ operated, e.g. Old Welsh elinou, Middle Welsh elin, Middle \& Modern Breton elin, Cornish elyn, elin 'elbow' < ${ }^{*}$ olin $n^{\circ}$ vs. the Gaulish hydronym Olina (Ptolemy: II.8.2: 'O $\lambda$ 'vo; see Holder II.844) and Old Irish uilen, Gothic aleina 'elbow' etc. (Jones 1913: 92; Matasović 2009: 297-8). This means that *eriro- is also derivable from *oriro-. With regard to the tendency to dissimilation of the type $r \ldots r>r \ldots l$ or $l \ldots r$ (Jones 1913: 160), it is possible to speculate that the Brittonic *eriro- can represent a relatively late formation reinterpreted as the reduplication (cf. Middle Welsh and Middle Breton erer or Armenian oror 'seagull' - see Olsen 1999: 207; Martirosyan 2010: 538) from primary *erilo- and further *orilo-.

The forms discussed here allow us to formulate the following partial reconstructions:

\begin{tabular}{||l||l|l||}
\hline \multicolumn{1}{|c|}{ Branch } & Branch protoform & Projection in Late Indo-European \\
\hline \hline Slavic & *orblb & *orilo- \\
\hline Baltic & *arelis & *oreliyo- \\
\hline Goidelic & *elVros & $\begin{array}{l}* \text { ill[o]ro- < *orilo- or *el[o]ro- } \\
\text { *orelo- }\end{array}$ \\
\hline Brittonic & *eriros & *eri[l]o- < *orilo- \\
\hline Gaulish & ?NL Orilus & *orilo- \\
\hline $\begin{array}{l}\text { 'Palaeo- } \\
\text { Balkanian' }\end{array}$ & ?NV Oroles $\sim$ & <orelo-? \\
\hline \hline
\end{tabular}

$\mathrm{NL}$ - nomen loci; $\mathrm{NV}$ - nomen viri. 
If the preceding argument is correct, the primary root was really $* \mathrm{H}_{3} \mathrm{er}$ and its extension in Balto-Slavic, Celtic and perhaps 'Palaeo-Balkanian' was really in $-l-$.

\section{Balto-Slavic words for 'swan'}

Baltic m. *gulbjas > Lithuanian gul̃bis, Latvian gùlbis, Prussian gulbis 'swan', f. *gulbijā > Lithuanian gulbẽ id., corresponds exactly to Slavic $*_{g z l b b}$, reconstructible on the basis of Serbo-Croatian gûb id. (ESSJ: VII.190; Toporov 1975-90: II.332). Better documented is the voiceless variant $* k b l p b$ id. This traditionally accepted comparison (BSW: 101) has been classified as an exclusive Balto-Slavic isogloss without any deeper etymology.

However, a key to this etymology can be found in the Celtic word for 'beak':

Celtic *gulbā, -iā \& *gulbino- 'beak' (Stokes \& Bezzenberger 1894: 115; Matasović 2009: 168-9).

Gaulish *gulbia > Latin gulbia (Isidore of Seville), cf. Old Brittonic Re-gulbium 'name of a promontory';

Middle Irish gulba f. 'beak, jaw', gulban m. gl. aculeum, i.e. 'beak, sting'.

Old Welsh m. and f. gilbin 'acumine', Middle Welsh gylf, gylfin, gylfant 'beak', Old Breton golbin, golbinoc gl. acc. rostratam, Middle Breton golff, Modern Breton golv 'without tail', Old Cornish gilb gl. foratorium, gl. geluin rostrum.

Semantic motivation in the ornithological terminology based on the word 'beak' has its analogy e.g. in Germanic *snipōn-, *snippan- 'snipe': Norwegian snippa 'beak' (Falk \& Torp 1909: 523).

If this solution is acceptable, it is not necessary to speculate about any pre-Celtic substrate source of the Celtic word.

\section{Is 'fox' a Celto-Baltic or Celto-Slavic isogloss?}

Irish lois f. 'fox' (Dinneen 1927: 672 who also quotes variants loise, luis) is without any unambiguous etymology. Macbain (1911: 232) reconstructed Celtic *luxo-, deriving it from IE *lukss- 'lynx'. Jones (1953: 43) saw the closest cognate in Cornish lostek 'fox', deriving both from Celtic *losto-/a 'tail' (Old Irish los(s), Welsh llost $\mathrm{f}$., Cornish \& Breton lost m., Stokes 1894: 256; but Elsie 1979: 137 reconstructs *lust- 'tail', comparing it with Old Icelandic lustr 'cudgel'). Finally, Mann (1984-7: 
17) included Irish lois in his entry *alōw-p $\breve{e ̂ k} s$ 'howling dog, fox'. Among these solutions the derivation from 'tail' looks most convincing, cf. Old Indic (Śilarika) lomataka- 'fox' vs. lüma- 'tail' or Germanic *fuxōn- and *fuxsa- 'fox', Torwali puš, Khowar pūši id. < Indo-Aryan *pucchī vs. Old Indic púccha- 'tail' etc. But there are also other possibilities for the internal reconstruction of Irish lois(e): (a) *lops $\bar{\imath}$, -i $\bar{a}-$; (b) *loips $\bar{a}$ (concerning the development $*_{-}$-ps- > -s-, cf. Old Irish ós, úas 'over, up' < *oup-su, see Pokorny 1959: 1107).

The alternatives (a) and (b) have their promising cognates in Baltic and Slavic respectively, but not together, since they exclude one another:

(a) Baltic *lapsā f. continues in Latvian lapsa 'fox', while the unique lapse, lapsis attested only in Manuale Lettico-Germanicum can reflect *lapsijā, -ijas (Mühlenbach \& Endzelin 1927: II.422; Karulis 1992: I.501). The masculine counterpart *lapas may be identified in Kurish laps m. (El Mogharbel 1993: 245) and Yatvingian tapf (Zinkevičius 1984: 14), cf. Lithuanian sẽnas 'old' vs. Yatvingian Jenf. The component laps- in the Lithuanian river name Laps-kójis, lit. 'fox's leg', represents more probably the syncopated genitive lapes (Vanagas 1981: 181).

The asigmatic variant *lapija $\mathrm{f}$. appears in Prussian lape (Elbing Vocabulary \#658 'Vochz'), Lithuanian lãpe (Bammesberger 1970: 38-43; Toporov 1975-90: V.83-9). Identifying the same suffix $*$-iy $\bar{a}$ in the feminine vilke 'she-wolf', Bammesberger (1970: 39) assumes the following development: ${ }^{*} w_{0} l k^{w}-\bar{l}-\left(=\right.$ Old Indic f. $\left.v_{o} k \bar{l}-\right)+$ feminine marker $*_{-} \bar{a}>$ Baltic *vilk-ij- $\bar{a}>$ Lithuanian vilke. This idea also implies the existence of the form *lapas corresponding to the masculine vilkas (cf. Kurish laps, Yatv. lap $\int$ analyzed above). The Baltic nom. sg. ending *-as can indicate not only the masculine $o$-stem, but also the neuter es-stem with the nom. sg. in *-os (cf. Brugmann 1906: 524 quoting e.g. Lithuanian kvãpas = Latin vapor, gen. -ōris). If we accept this hypothesis, the following scenario could explain the origin of both variants: the verbal root *lAp- $\left(A=*^{*} O\right.$ or $\left.* a\right)$ extended in -es- resulted in the abstract noun *lAp-os, gen. *lAp-es-os. Its plural *lAp-es-eH $H_{2}$ could be reinterpreted as the feminine *lAp(e)sa $>$ Latvian lapsa. On the other hand, the nom. sg. *lAp-os gave Baltic *lapas and this form could be reinterpreted as a masculine. Later the corresponding feminine *lap- $\bar{\imath}$ was formed, too; its final shape came into being by adding the most wide-spread feminine

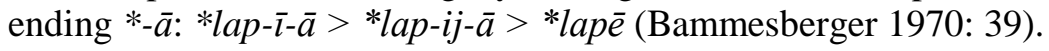


The hypothesis based on the primary $s$-stem explains sufficiently the existence and mutual relations of both lapsa and lape forms. The same cannot be said about the alternative derivation of the sigmatic extension from $*_{-} \hat{k}$ -

(b) The second alternative is as follows: Slavic m. *lîsb continues in Old Church Slavonic liš, Serbo-Croatian dial. lîs, Slovenian lìs, gen. lísa, Upper Sorbian, Polish lis, Kashubian lës, Slovincian also las, Belorussian lis, Ukrainian lys, Russian (archaic) lís. In Czech, lis has shifted its meaning to 'press' (= 'choking'); f. *lisa is attested in Bulgarian lísa (further the dialectal forms as lesá, ljása reflecting *lěsa; they are probably influenced by les $<$ *lěs $b$ 'forest'), Macedonian, Old Czech lisa, Belorussian, Russian lisá, Ukrainian lýsa. The most widespread form is extended in *-ica: Church Slavonic \& Macedonian lisica, Bulgarian lisíca, dial. lesíca, Serbo-Croatian lìsica, Slovenian lisíca, dial. lesica, Polabian laísaíća, Polish lisica, Belorussian and Russian lisíca, Ukrainian lysýcja. This form is missing in Slovak, Czech and Sorbian, where lišk $k a$ and liška respectively appear. With respect to the complementary distribution it seems probable to identify here the diminutive *lisičbka (Bulgarian lisička, Slovenian lisîčka, Polish dial. lisiczka, Ukrainian lysýčka, Russian lisička), assimilated in *lišička and finally syncopated in *liščka > liška (cf. Machek 1971: 336 and Trubachev in ESSJ: XV.142, 151).

The accentuation *lîs $b$ indicates the original diphthong $*_{-e i-}$ (Sławski 1970: 277-8). The absence of the change $s>x / s$ (the RUKI-law) implies the original cluster $*_{-} P s$ - or $*_{-} T s-$. The reflex $* \hat{k}$ should be taken into account, too, but for the same arguments as in Baltic it is omitted. Consequently, the reconstruction $*(w)$ leipso-/ $\bar{a}$ has usually been chosen. But among numerous zoonyms with the similar consonantal skeleton $(*(w)-l-p-(s-))$ there is only one form compatible also with Slavic in vocalism, namely Irish lois, if it is a continuant of *loips $\bar{a}$. The only difference lies in the root vocalism, namely the opposition $e i$ vs. oi can reflect the old ablaut, cf. e.g. Old Irish froech, Welsh grug 'heather'

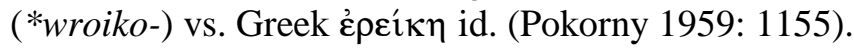

The preceding analysis isolated the primary ('Brugmannian') roots *lop- or *lap- (*lap-) in Baltic and *leip- in Slavic. The Irish counterpart is derivable from both *lop- (but not from *lap-) and *leip-. Although *lop- (and *lap-) and *leip- are not directly compatible, they agree in semantics, which the following examples demonstrate: 
(a) *lop-/*lap-: Ossetic loefince 'bright ray, light' (Abaev 1973: 19; the vowel of the first syllable reflects Iranian $* a$ and not $* i<\mathrm{IE} * a$ $=* H$ ), Hittite lap- 'to glow', lappiya- 'fever', (?) GIŠlappiya-

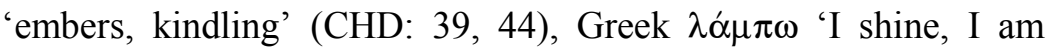

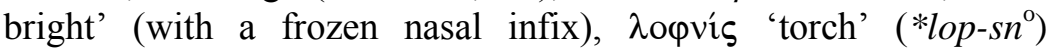
(Chantraine 1968: 617, 647), Old Irish lassaim 'I flame', lassair 'flame', Welsh llachar 'coruscus, igneus' (*laps-; but also *laks-) vs. Old Irish loscaim 'I burn', Welsh llosgi 'urere' (*lop-sk-) (Stokes 1894: 238, 256); Old English lëven, -in 'lightning' (Holthausen 1921: 62), Lithuanian lópé, Latvian lãpa 'torch', Prussian lopis [Elbing Vocabulary 44] 'Flamme' (Fraenkel 1962-5: 386; Toporov 1975-90: V.353ff.). The Baltic forms reflect *lapp- in 'Brugmannian' reconstruction, i.e. ${ }^{*} l e \mathrm{H}_{2} p$ - in the laryngealistic reconstruction. The 'Brugmannian' pair *lap- \& *lop- is compatible only starting from the apophonic opposition zero grade: $o$-grade, i.e. $* l_{0} H p$-: *lHop-. The identification $* H={ }^{*} H_{2}$ (Beekes 1988: 27, 36 ) is based on Baltic $*_{\bar{a}}$ (different from $* \bar{o}$ ), pre-Celtic *laps- or *laks- and Greek $\lambda \alpha \alpha \mu \pi \omega$, rather differing from the formation of nasal presents in Greek (cf. e.g. Hirt 1902: 372-7 and Kuiper 1937: $118,152)$.

(b) *leip-/*loip-: Irish laom 'blaze' (*loipsmº), Old Icelandic lifa 'to blaze', leiptr 'lightning', Lithuanian liepsnà 'flame', lìpst 'burns', pãlipas 'Holzspan', Latvian liesma 'flame', lipt 'glänzen, anzünden' (Pokorny 1959: 653; Fraenkel 1962-5: 366-7; Mann 1984-7: 704).

(a/b) Old Irish loise 'flame, blaze; splendour' (DIL: L-190-91) is derivable from both *lopsiā and *loipsā.

The preceding thoughts imply that the primary abstract noun *lop-esproposed above could mean 'brightness'. Similarly, in Slavic we may expect a synonymous primary abstract noun *leip-es-. Thematized, it gave *leips-o-/ $\bar{a}$ 'that characterized by brightness'. The same process is evident for Indo-Iranian *vatsá- 'calf' derivable from *wét-es- 'year' (Mayrhofer 1995: 495). It is quite possible that almost all the animal names in $-s$ originated in a similar way (cf. Brugmann 1906: 546-7).

The semantic motivation 'fox' = 'shining', i.e., 'that with shining hair or tail', is well-known, cf. Old Icelandic skolli 'fox' vs. skulla 'to 
shine' (Vries 1962: 498) or Greek $\Lambda$ ó $\mu \pi$ ovpos 'name of a dog', lit. 'that with shining tail', or the appellative f. $\lambda \alpha$ '́ $\mu \pi$ ovprs 'fox' (Aeschylus; see Chantraine 1968: 617).

Masaryk University, Brno

\section{Abbreviations}

BSW = Trautmann, R., 1923 [1970], Baltisch-Slavisches Wörterbuch, Göttingen.

CHD = Güterbock, H.G. \& Hoffner, H.A., 1989, eds., The Hittite Dictionary of the Oriental Institute of the University of Chicago, L-N, Chicago.

DIL = Quin, E.G. et al., 1990, eds.. Dictionary of the Irish Language (Compact Edition), Dublin.

Elbing Vocabulary = Mažiulis 1988-93.

ESSJ = Trubachev, O.N. et al., 1974ff., eds., Etimologičeskij slovaŕ slavjanskix jazykov [Etymological Dictionary of the Slavic Languages], Moscow.

GPC = Geiriadur Prifysgol Cymru I (A-Ffysur), 1950-67, Caerdydd.

HED = Puhvel, J., 1984-91, Hittite Etymological Dictionary 1-2 (A, E \& I), $3(\mathrm{H})$, Berlin - New York - Amsterdam.

LIV = Rix, H., \& Kümmel, M. et al., 2001, eds., Lexikon der indogermanischen Verben $_{2}$, Wiesbaden.

\section{References}

Abaev, V.I., 1973, Istoriko-ètimologičeskij slovaŕ osetinskogo jazyka [Etymological Dictionary of the Ossetian Language], vol. 2, Leningrad.

Andersen, H., 1996, Reconstructing Prehistorical Dialects: Initial Vowels in Slavic and Baltic, Berlin - New York.

Bammesberger, A., 1970, 'Litauisch lãpè und lateinisch volpēs', in: Rūḳe Dravina, V., ed., Donum Balticum: Fs. Christian S. Stang, Stockholm, 3843.

Beekes, R.S.P., 1988, 'PIE. RHC- in Greek and Other Languages', IF 93, 22-45.

[Bielowski, A., ed., 1853,] Trogus, Pompejus, Fragmenta: quorum alia in codicibus manuscriptis Bibliothecae Ossolinianae invenit, alia in operibus, scriptorum maximam partem Polonorum, iam vulgatus primus 
animadvertit, fragmenta pridem nota adiunxit, ac una cum prologis historiarum philippicarum et criticis annotationibus, Leopolis.

Buck, C.D., 1949, A Dictionary of Selected Synonyms in the Principal Indo-European Languages, Chicago.

Bernardo Stempel, P., de 1999, Nominale Wortbildung des älteren Irischen, Tübingen.

Blažek, V., 1997, 'Lisb', Etymologický slovnik jazyka staroslověnského 7, Praha, 427.

Brugmann, K., $1906_{2}$, Grundriss der vergleichenden Grammatik der indogermanischen Sprachen 2.1. Strassburg.

Chantraine, P., 1968-, Dictionnaire étymologique de la langue grecque, Paris.

Detschew, D., 1957, Die thrakischen Sprachreste, Wien.

Dineen, P., 1927, An Irish-English Dictionary, Dublin.

El Mogharbel, Ch., 1993, Nehrungskurisch. Dokumentation einer moribunden Sprache, Frankfurt am Main.

Elsie, R.W., 1979, The Position of Brittonic, Bonn (Inaugural Dissertation).

Endzelin, J. \& Hausenberg, E., 1934-8, Ergänzungen und Berichtigungen zu K. Mühlenbachs Lettisch-deutschem Wörterbuch I-II, Riga.

Falk, H. \& Torp, A., 1909, Wortschatz der Germanischen Spracheinheit, Göttingen.

Fraenkel, E., 1962-5, Litauisches etymologisches Wörterbuch, Heidelberg - Göttingen.

Griepentrog, W., 1995, Die Wurzelnomina des Germanischen und ihre Vorgeschichte, Innsbruck.

[Groningen, B. A., van, ed., 1963,] Herodotus. Historiën, Leiden.

Hirt, H., 1902, Handbuch der griechischen Laut- und Formenlehre: eine Einführung in das sprachwissenschaftliche Studium des Griechischen. Heidelberg.

Holder, A. T., 1896-1907, Alt-Celtischer Sprachschatz, Bd. I-III. Leipzig.

Holthausen, F., 1921, 'Wortdeutungen', IF 39, 62-74.

[Hude, K., ed., 1898-1901,] Thucydides, Historiae, Leipzig.

Jones, J. M., 1913, A Welsh Grammar, Oxford.

Jones, D. M., 1953, 'Etymological notes', Transactions of the Philological Society, 43-51.

Karulis, K., 1992. Latviešu etimologijas vārdnīca, Riga, 2 vols.

Kloekhorst, A., 2008, Etymological Dictionary of the Hittite Inherited Lexicon, Leiden - Boston. 
Kretschmer, P., 1896, Einleitung in die Geschichte der griechischen Sprache, Göttingen.

Kuiper, F.B.J., 1937, Die indogermanischen Nasalpräsentia, Amsterdam. Lidén, E., 1929, 'Zur vergleichenden Wortgeschichte', KZ 56, 211-22.

Macbain, A., 1911, An Etymological Dictionary of the Gaelic Language, Stirling.

Machek, V., 1971, Etymologický slovník jazyka českého [Etymological Dictionary of the Czech Language], Praha.

Mann, S.E., 1984-7, An Indo-European Comparative Dictionary, Hamburg.

Marcellinus, 1840, Vita Thucydidi, in: Thucydidis Historia belli Peloponnesiaci acc. Marcellini Vita, Scholia Graeca emendatius expressa, et indices nominum et rerum. Paris.

Martirosyan, H. K., 2010, Armenian Inherited Lexicon, Leiden - Boston.

Matasović, R., 2009, Etymological Dictionary of Proto-Celtic, Leiden Boston.

Mayrhofer, M., 1995, Etymologisches Wörterbuch des Altindoarischen, Heidelberg, 2 vols.

Mažiulis, V., 1988-93, Prūsu kalbos etimologijos žodynas. I (A-H). II (IK), Vilnius.

Mühlenbach, K., \& Endzelin, J., 1925-7, Lettisch-Deutsches Wörterbuch, Riga, 2 vols.

Olsen, B. A., 1999, The Noun in Biblical Armenian, Berlin - New York.

Pedersen, H., 1909, Vergleichende Grammatik der keltischen Sprachen I, Göttingen.

Pokorny, J., 1959, Indogermanisches etymologisches Wörterbuch, Bern München.

Rapallo, U., 1991, 'Cimr. eryr 'aquila' (ExR-): problemi e perspective della ricerca etimologica', AISN 13, 129-170.

Robinson, F.N., 1908, 'The Irish Lives of Guy of Warvick and Bevis of Hampton', Zeitschrift für celtische Philologie 6, 9-180.

[Nobbe, C. F. A., ed., 1966,] Ptolemaeus, Claudius, Geographia, Hildesheim.

Schrijver, P., 1991, The Reflexes of the Proto-Indo-European Laryngeals in Latin. Amsterdam - Atlanta.

Schrijver, P., 1995, Studies in British Celtic Historical Phonology, Amsterdam - Atlanta.

Schulze, W., 1908, 'Vom idg. l-Suffix', in: Jagić-Festschrift: Zbornik u slavu Vatroslava Jagića, Berlin, 343-7. 
Schulze, W., 1913, 'Der Fuchs', KZ 49, 287-8.

Schumacher, S., 2004, Die keltischen Primärverben. Innsbruck.

Schuster-Šewc, H., 1981-4, Historisch-etymologisches Wörterbuch der ober- und niedersorbischen Sprache 2, Bautzen.

Skok, P., 1971-4, Etimologijski rječnik hrvatskoga ili srpskoga jezika [Etymological Dictionary of Croatian and Serbian Language], Zagreb, 4 vols.

Stawski, F., 1970, Stownik etymologiczny języka polskiego IV [Etymological Dictionary of the Polish Language], Kraków.

Smoczyński, W., 2007, Stownik etymologiczny języka litewskiego [Etymological Dictionary of the Lithuanian Language], Wilno.

Stokes, W. \& Bezzenberger, A., 1894, Urkeltischer Sprachschatz, Göttingen.

Toporov, V. N., 1975-90, Prusskij jazyk: Slovar' [Dictionary of the Prussian Language], Moscow, 4 vols.

Thurneysen, R., 1918, 'Irisches', KZ 48, 48-75.

Thurneysen, R., 1946, A Grammar of Old Irish, Dublin.

Vanagas, A.P., 1981, Lietuviu hidronimiu etymologinis žodynas, Vilnius.

Vasmer, M., 1953-8, Russisches etymologisches Wörterbuch, Heidelberg, 3 vols.

Vries, J. de, $1962{ }_{2}$, Altnordisches etymologisches Wörterbuch, Leiden.

Zinkevičius, Z., 1984, 'Pol'sko-jatvjažskij slovarik?', Balto-slavjanskie issledovanija 1983, 3-30.

\section{Acknowledgements}

This study originated in cooperation with the Centre for the Interdisciplinary Research of Ancient Languages and Older Stages of Modern Languages (MSM 0021622435) at Masaryk University, Brno, and was supported by the grant no. IAA901640805. I am grateful to John Bengtson for his kind correction of my English. 